\title{
Evaluation on Front Line Demonstrations on Pigeon Pea [(Cajanus cajan (L.) Millsp.)] Crop in Saran District, Bihar
}

\author{
Surendra Prasad*, R. K. Jha, A. K. Singh, Pankaj Kumar, \\ S. S. Patel, J. C. Chandola and Vijay Kumar
}

Krishi Vigyan Kendra, Manjhi, Saran, Dr. Rajendra Prasad Central Agricultural University, Pusa, Bihar, India

*Corresponding author

\section{Keywords}

Front line demonstration, NDA-1,

Technology index, Extension gap, B:C ratio

Article Info

Accepted:

18 March 2021

Available Online:

10 April 2021

\section{A B S T R A C T}

The front line demonstrations (FLD) programme on pigeon pea crop were conducted during 2011-12 and 2012-13 in Saran District, Bihar. The farmer's field were selected from different village (0.4ha) from the district. These demonstrations focused on increased productivity and replacement of old variety with promising high yielding improved variety Narendra Arhar 1 (NDA-1) and get the feedback from farmers on the performance of pigeon pea variety. The study revealed that over years, NDA-1 variety was superior over traditional farmer's practices. The economic influence of pigeon pea observed i.e. net return (Rs. 41066), Benefit cost ratio (4.10:1), extension gap (4.56 q/ha), and technology index (17.80\%). By conduction of front line demonstration (FLDs) on farmer's field there was significant increase in knowledge level of the farmers and majority of farmer's showed high level of satisfaction about demonstrated technologies.

\section{Introduction}

Pigeonpea [(Cajanus cajan (L.) Millsp.)] is cultivated in tropical and sub-tropical areas between $300 \mathrm{~N}$ and $300 \mathrm{~S}$ latitude. It is an important grain legume of Asia (especially, the Indian subcontinent), Latin America and Eastern and Southern Africa. Globally, it is grown on $\sim 5$ million hectares (m ha) in about 82 countries of the world. Pigeon pea has a unique place in Indian farming and India accounts for about $90 \%$ of the global production. It is the second most important pulse crop next to chickpea, covering an area of around $4.42 \mathrm{~m}$ ha (occupying about $14.5 \%$ of area under pulses) and production of 2.86 $\mathrm{mt}$ (contributing to $16 \%$ of total pulse production) and productivity of about 707 $\mathrm{kg} / \mathrm{ha}$. It is mainly consumed as dry split dhal throughout the country besides several other uses of various parts of pigeon pea plant. It is an excellent source of protein (20-22\%), 
supplementing energy rich cereal diets in a mainly vegetarian population (Saxena et al., 2010). It is mainly grown as intercrop with urdbean, moonbean, castor, sorghum, soybean, cotton maize and groundnut in states, Maharashtra, Karnataka, Andhra Pradesh, Telangana, Madhya Pradesh, Uttar Pradesh, Bihar, Gujarat, Jharkhand, Rajasthan, Odisha, Punjab and Haryana. Pigeon pea is a multipurpose crop that fits very well in the context of sustainable agriculture. The highest yield has been recorded by Bihar $(1695 \mathrm{~kg} / \mathrm{ha})$ followed by West Bengal (1450 kg/ha), Haryana (1100 kg/ha) and Gujarat (1082 $\mathrm{kg} / \mathrm{ha}$ ). The lowest yield has been observed in the state of A.P. (536 kg/ha) followed by C.G. $(575 \mathrm{~kg} / \mathrm{ha})$ and Karnataka (591 kg/ha). In Bihar, Saran district has the sizeable area under pigeon pea cultivation but the productivity level is very low. The reasons for low productivity about newly released crop production technologies and their management practices have not applied in the farmer's field. Keeping the above point in view, the FLDs on pigeon pea using production improved technologies was conducted with the objective of showing the productive potential of the new production technologies under actual farm situation.

\section{Materials and Methods}

The present study was conducted at Krishi Vigyan Kendra, Manjhi, Saran under Dr. Rajendra Prasad Central Agricultural University, Pusa, Bihar in five adopted village (Nandpur, Samahauta, Dumari, Stalpur and Bareja) during Kharif season in 2011-12 and 2012-13. Before conducting FLDs, a list of farmers was prepared from group meeting and specific skill training was imparted to the selected farmers regarding different aspect of cultivation (Venkattakumar et al., 2010). The difference between the demonstration package and existing farmers practice are given in Table 1.
In demonstration plots, use of quality seeds of improved varieties, Seed rate, Method sowing and timely weeding, need based pesticide, weedicide as well as balanced fertilization were emphasized and comparison has been made with the existing practices (Table 1). The necessary steps for selection of site and farmers, lay out of demonstration etc. were followed as suggested by Choudhary (1999). The traditional farmer practices were maintained in case of local checks. The data output were collected from both FLD plots as well as control plots and finally the extension gap, technology gap, technology index along with the benefits cost ratio were work out (Samui et al., 2000) as given below:

Technology gap

$=$ Potential yield - Demonstration yield

Extension gap

$=$ Demonstration yield - Farmers yield

Technology index $(\%)$

$=($ Technology gap $\times 100) /$ Potential yield

International Crops Research institute for the Semi-Arid Tropics (ICRISAT), Patancheru, Hyderabad, India

\section{Results and Discussion}

The result of 45 front line demonstration (FLDs) conducted during 2011-12 and 201213 in 18 ha area at five adopted village in Saran District of Bihar state. The results finding obtained from the present study have been distributed in Yield and Economics of pigeon pea cultivation as per Table 2 and Table 3. In Table 1 is conducted that demonstration yield of NDA-1 variety performance better than traditional farmer practices. The NDA-1 recorded maximum and minimum yield in the kharif year 2011-12 and 2012-13 with $15.47 \mathrm{q} / \mathrm{ha}$ and 14.12/ha, respectively. The average yield of two years 
was recorded $14.80 \mathrm{q} / \mathrm{ha}$ as compared to local variety $10.24 \mathrm{q} / \mathrm{ha}$. The per cent increase in yield was ranging from 42.19 to 46.77 during the study. The results are in conformity with the finding of Suthar et al., (2016), Tomer et al., (2003) and Tiwari and Saxena (2001). The results clearly indicate the positive effects of FLDs over existing farmer practices toward enhancing the yield of pigeon pea. Results of Table 2 revealed that yield of the front line demonstration and potential yield of the crop was compared to estimate the yields which were further categorized into technology and extension gaps. The technology and Extension gaps were ranged between 2.53 - 3.88 q/ha and $4.19-4.93$ q/ha with a mean of two years $3.21 \mathrm{q} / \mathrm{ha}$ and $4.56 \mathrm{q} / \mathrm{ha}$ during period of study. Technology and Extension gaps indicated the needs to educate farmers more and more through various extension means to increase awareness and adoption of improved variety especially NDA-1for narrow down the both gaps. The technology gap increased may be attributing to the dissimilarity soil fertility status and weather conditions (Mitra and
Samajdar, 2010). The technology index shows the feasibility of the improved technology at the farmer's fields. The lower the value of technology index more is the feasibility of the technology. As such, fluctuation in technology index was from 14.05 to 21.55 per cent during study period (Table 2). These findings corroborate with the finding of Mokidue et al., (2011). The Year wise economics of pigeon pea cultivation with adoption of improved technology and farmers practices has been presented in Table 3. The adoption of improved technology under FLDs recorded higher average gross returns (54321 Rs/ha), net returns (41066 Rs/ha) and B: C ratio (4.10:1) compared to farmers practice i.e. 37571 Rs/ha, 25354 Rs./ha, 3.07:1, respectively. Varietal characters of NDA-1 (stalk, straw yield and price of pigeon pea grain) play additional role for higher gross return. This fluctuating income trend was obtained due to variable price of pigeon pea and improper marketing system. These results are in conformity with the findings of Katare et al., (2011).

Table.1 Comparison between frontline demonstrations and farm's practices

\begin{tabular}{|c|c|c|c|}
\hline $\begin{array}{c}\text { S. } \\
\text { No. }\end{array}$ & Particulars & $\begin{array}{c}\text { Existing farmer } \\
\text { practices }\end{array}$ & Improved practices on demonstration \\
\hline $\mathbf{1}$ & Variety & Use of local variety & Narendra Arhar -1 \\
\hline $\mathbf{2}$ & Time of Sowing & 25 June to 15 July & 25 June 15 July \\
\hline $\mathbf{3}$ & Method of sowing & Broadcasting method & Line sowing \\
\hline $\mathbf{4}$ & Seed rate & 30-40 kg/ha & 20 kg/ha \\
\hline $\mathbf{5}$ & Seed treatment & No seed treatment & $\begin{array}{c}\text { Seed treatment by Fungicides and bio- } \\
\text { fertilizer }\end{array}$ \\
\hline $\mathbf{6}$ & Fertilizer dose & No fertilizer use & 20 kg/ha Nitrogen and 60 kg/ha phosphorus \\
\hline $\mathbf{7}$ & Weed management & Hand weeding & $\begin{array}{c}\text { Use of pre emergence weedicide } \\
\text { pendimethalin }\end{array}$ \\
\hline $\mathbf{8}$ & Plant protection & $\begin{array}{c}\text { No use any plant } \\
\text { protection technique }\end{array}$ & \begin{tabular}{c} 
Adoption of IPDM practices \\
\hline
\end{tabular}
\end{tabular}


Table.2 Yield of pigeon pea by production technologies and high yielding varieties over local farmer's variety in 2011-12 and 2012-13

\begin{tabular}{|c|c|c|c|c|c|c|c|c|c|}
\hline \multirow[t]{2}{*}{ Years } & \multirow{2}{*}{$\begin{array}{c}\text { No. of } \\
\text { demonstration }\end{array}$} & \multirow{2}{*}{$\begin{array}{l}\text { Area } \\
\text { (ha) }\end{array}$} & \multicolumn{3}{|c|}{ Yield (q/ha) } & \multirow{2}{*}{$\begin{array}{c}\% \\
\text { increas } \\
\text { e over } \\
\text { control }\end{array}$} & \multirow{2}{*}{$\begin{array}{c}\text { Technol } \\
\text { ogy gap } \\
\text { (q/ha) }\end{array}$} & \multirow{2}{*}{$\begin{array}{c}\text { Extensio } \\
\text { n gap } \\
\text { q/ha) }\end{array}$} & \multirow{2}{*}{$\begin{array}{l}\text { Technolo } \\
\text { gy index } \\
(\%)\end{array}$} \\
\hline & & & Potential & $\begin{array}{l}\text { Dem } \\
\text { onstr } \\
\text { ation }\end{array}$ & $\begin{array}{c}\text { Local } \\
\text { (farmer's } \\
\text { plot) }\end{array}$ & & & & \\
\hline 2011-12 & 25 & 10 & 18 & 15.47 & 10.54 & 46.77 & 2.53 & 4.93 & 14.05 \\
\hline 2012-13 & 20 & 8 & 18 & 14.12 & 9.93 & 42.19 & 3.88 & 4.19 & 21.55 \\
\hline Mean & - & - & 18.00 & 14.80 & 10.24 & 44.48 & 3.21 & 4.56 & 17.80 \\
\hline
\end{tabular}

Table.3 Economic influence of pigeon pea by production technologies over farmer's field in 2011-12 and 2012-13

\begin{tabular}{|c|c|c|c|c|c|c|c|c|}
\hline \multirow{2}{*}{ Years } & \multicolumn{2}{|c|}{ Gross Return } & \multicolumn{2}{c|}{$\begin{array}{c}\text { Cost of } \\
\text { cultivation }\end{array}$} & \multicolumn{2}{c|}{ Net return } & \multicolumn{2}{c|}{ B:C ratio } \\
\cline { 2 - 9 } & Demo & Local & Demo & Local & Demo & Local & Demo & Local \\
\hline $\mathbf{2 0 1 1 - 1 2}$ & 55692 & 37944 & 13876 & 12496 & 41816 & 25448 & 4.01 & 3.04 \\
\hline $\mathbf{2 0 1 2}-13$ & 52950 & 37238 & 12635 & 11978 & 40315 & 25260 & 4.19 & 3.10 \\
\hline Mean & $\mathbf{5 4 3 2 1}$ & $\mathbf{3 7 5 9 1}$ & $\mathbf{1 3 2 5 6}$ & $\mathbf{1 2 2 3 7}$ & $\mathbf{4 1 0 6 6}$ & $\mathbf{2 5 3 5 4}$ & $\mathbf{4 . 1 0}$ & $\mathbf{3 . 0 7}$ \\
\hline
\end{tabular}

Sale rate of pigeon pea grain during 2011-12: Rs. 3600/q and 2012-13 : Rs 3750/q

The present study observed that cultivation of pigeon pea with improved technologies has been found more productive and grain yield might be increase up to 44.48 per cent.

Wide technological and extension gaps existed between research recommendation and traditional farmer practices. However, the yield level under FLD was superior over local pigeon pea variety and performance and potentiality of this variety could be further improved by adopting recommended management practices.

Hereof, it can be concluded from the study that increased yield was due to adoption of variety NDA-1 and conducting frontline demonstrations of proven technologies yield potentials of crop can be increased to greater extent. This will subsequently increase the yield as well as the livelihood of the farming community.

\section{References}

Chaudhary, B. N. (1999). Krishi Vigyan Kendra-a guide for KVK manager. Division of Agriculture Extension, ICAR, pp.73-78.

Katare, S., Pandey, S. K. and Mustafa, M. (2011). Yield gap analysis of rapeseed mustard through front line demonstration. Agric. Update, 6(2) : 57.

Mitra, B. and Samajdar, T. (2010). Field gap analysis of rapeseed-mustard through front line demonstration. Agric. Exten. Rev., 22 : 16-17.

Mokidue, I., Mohanty, A. K. and Sanjay, K. (2011). Correlating growth, yield and adoption of urdbean technologies, Indian J. Extn. Edu., 11 (2) : 20-24.

Samui, S. K., Maitra, S., Roy, D. K., Mandal, A.K. and Saha, D. (2000). Evaluation on front line demonstration on groundnut (Arachis hypogea L.). J. 
Indian Soc. Coastal Agric. Res., 18 (2): 180-183.

Saxena K B, Kumar R V and Sultana R. 2010. Quality nutrition through pigeon pea-a review. Health, 2 (11) 1335-1344.

Suthar, J. V., Chawda, S. K., Patel, A. T. Pastagia, J. J and Patel, B. B., (2016). Impact of front line demonstration the yield of poha rice (Oryza sativa) in Surat district. J. Bio. Innov. 5 (4): 588593.

Tiwari, K. S. and Saxena, A. (2001). Economic analysis of FLD of oilseed in Chhindwara. Bhartiya Krishi
Anusandhan Patrika, 16 (3 \& 4): 185189.

Tomar, L. S., Sharma, B. P. and Joshi, K. (2003). Impact of front line demonstration of soybean in transfer of improved technology, J. Extn. Edu., 22 (1) : 139 .

Venkattakumar, R., Ramana Rao, S. V., Padmaiah, M. and Madhuri, P. (2010). Production constraints and information needs of oilseeds growers in Andhra Pradesh. Agric. Extn. Rev., 22 (2):2528.

\section{How to cite this article:}

Surendra Prasad, R. K. Jha, A. K. Singh, Pankaj Kumar, S. S. Patel, J. C. Chandola and Vijay Kumar. 2021. Evaluation on Front Line Demonstrations on Pigeon Pea [(Cajanus cajan (L.) Millsp.)] Crop in Saran District, Bihar. Int.J.Curr.Microbiol.App.Sci. 10(04): 745-749. doi: https://doi.org/10.20546/ijcmas.2021.1004.076 